\title{
Big batteries on wheels: converting diesel trains to battery electric can provide significant economic, environmental, and grid resilience benefits
}

\section{Natalie Popovich}

Lawrence Berkeley National Laboratory https://orcid.org/0000-0002-9460-2517

Amol Phadke ( $\square$ aaphadke@lbl.gov)

Lawrence Berkeley National Laboratory

\section{Elif Tasar}

University of California Berkeley

\section{Article}

Keywords: Locomotives, Diesel Generators, Air Pollution, Battery-electric Rail, Cost Parity, Grid Constraints

Posted Date: January 20th, 2021

DOI: https://doi.org/10.21203/rs.3.rs-142022/v1

License: (c) (i) This work is licensed under a Creative Commons Attribution 4.0 International License.

Read Full License

Version of Record: A version of this preprint was published at Nature Energy on November 11th, 2021. See the published version at https://doi.org/10.1038/s41560-021-00915-5. 


\section{Big batteries on wheels: converting diesel trains to battery electric can provide significant}

2 economic, environmental, and grid resilience benefits

4 Abstract

5 Nearly all locomotives in the U.S. are propelled by an electric drive that is powered by a diesel 6 generator, the air pollution from which contributes to more than 1,000 premature deaths every 7 year. Dramatic improvements in battery technology plus access to cheap renewable electricity 8 open the possibility of battery-electric rail. Given that locomotives already have an electric drive, 9 converting them to battery-electric primarily requires a battery car, which can be connected 10 directly to the drivetrain. We examine the case for a battery-electric U.S. freight rail sector and 11 find that one heavy-duty battery car can power a typical locomotive for 450 miles, three times the 12 average daily distance travelled by U.S. freight trains. We find that battery-electric trains can 13 achieve cost parity with diesel trains with electricity charging costs under 6 cents $/ \mathrm{kWh}$. We 14 illustrate how these costs can be achieved with access to wholesale electricity rates. Converting 15 the fleet to battery-electric would remove 37 million metric tons of carbon dioxide and generate 16 total sector cost savings of $\$ 250$ billion over 20 years, while introducing $238 \mathrm{GWh}$ of mobile 17 batteries that could address location-specific grid constraints during extreme events. 
Based on scientific consensus, global greenhouse gas (GHG) emissions must be reduced $45 \%$ from 2010 levels by 2030 to limit global warming to $1.5{ }^{\circ} \mathrm{C}$ and minimize climate catastrophe. ${ }^{1}$ The U.S. freight rail sector provides a unique opportunity for aggressive near-term climate action. It transports more goods than any other rail system in the world ${ }^{2}$ and depends on diesel fuel, which accounts for over $90 \%$ of the rail sector's total energy consumption. ${ }^{3}$ Currently transporting $40 \%$ of national intercity freight, ${ }^{4}$ its capacity is projected to double by $2050 .{ }^{5}$ Absent significant changes to its propulsion system, the U.S. freight rail system will be responsible for half of global diesel used in the freight rail sector by the same year. ${ }^{2}$ These diesel locomotives emit 37 million metric tons of $\mathrm{CO}_{2}$ each year and produce air pollution that causes about 1,500 premature deaths annually, accounting for $\$ 14.1$ billion in health damage costs ${ }^{6}$; these damages are almost three times those associated with all U.S. natural gas-based power generation. Despite being more fuel efficient than trucks, the locomotives produce close to twice the air pollution damages as heavyduty trucks per gallon of diesel consumed owing to less stringent pollution controls on 14 locomotives. ${ }^{6,7}$

Efforts to identify zero-emissions pathways for freight rail are underway, with national sectorwide emissions-reductions targets and more stringent Environmental Protection Agency emissions-reductions requirements for the U.S. freight rail sector. ${ }^{8}$ Two pathways have emerged for achieving zero emissions: rail network electrification via catenary and battery-powered locomotives. The catenary approach involves electrifying the entire rail network via overhead lines coupled with grid-scale storage of renewable energy, and it has been more thoroughly investigated. ${ }^{9,10}$ We consider the other pathway based on leveraging recent technological advances to add battery cars to existing diesel-electric locomotives. This approach obviates the infrastructure investment required by a catenary system, and, because of the temporal flexibility of battery charging, it allows rail operators to exploit existing surplus renewable energy sources at low prices.

Three recent developments support a U.S. transition to battery-electric rail: plummeting battery prices, increasing battery energy densities, and access to cheap renewable electricity for up to 12 hours per day. Between 2010 and 2020, battery energy densities tripled and battery pack prices declined $87 \% .{ }^{11}$ Some auto-makers are already achieving lithium-ion battery prices of $\$ 100 / \mathrm{kWh}^{12}$ Average industry prices are expected to reach $\$ 100 / \mathrm{kWh}$ by $2023^{13}$ and $\$ 55$ $\$ 65 / \mathrm{kWh}$ by $2030 .{ }^{14}$ At the same time, electricity from renewable sources costs about half as much as electricity from fossil fuels. ${ }^{15} \mathrm{~A}$ few studies have considered battery-electric rail propulsion, but their price estimates are outdated owing to the rapid innovation in battery technology. ${ }^{2,16}$ Previous studies have also relied on average electricity tariffs, which overestimate charging costs because they do not account for potential to charge batteries when surplus renewable electricity is available.

In this paper, we examine the case for zero-emission, battery-electric propulsion in the U.S. freight rail sector based on current and forecasted energy storage technologies combined with access to 
electrically connected battery cars could enable the sector to reduce emissions while realizing economic gains. In addition, the vast pool of locomotive batteries could be deployed to address location-specific grid constraints during extreme events.

Technical feasibility of battery-electric propulsion

\section{Powertrain}

Over $87 \%$ of U.S. locomotives are diesel-electric: a diesel engine drives an electric generator that powers traction motors to drive the axles. Such a train can be converted to battery-electric by adding one or more battery cars with wiring that delivers electricity to the drivetrain. A battery tender car could transmit electricity via cable to the locomotive's central electrical bus and then transmit that electricity to the traction motors. Alternating current (AC) and direct current (DC) traction motors have different retrofit requirements; both types are used in U.S. locomotives, although AC motors are increasingly common. The DC locomotive requires only cables and a charge controller from the battery tender car, incurring negligible cost. Each locomotive with an $\mathrm{AC}$ traction motor would require a transformer (we account for this cost under charging infrastructure in the electricity tariffs) and an onboard inverter for the 3.3-MW traction motor.

Range, size, energy consumption, and charging opportunities

The freight rail sector is almost 10 times more efficient than road-based freight, requiring about $1 / 10^{\text {th }}$ the energy per ton-mile. ${ }^{17,18}$ This advantage provides trains with a margin for adding the battery-related weight, volume, and energy consumption needed to achieve a sufficient daily range while maintaining very high efficiency. In addition, the nature of battery technology and rail operations provides plentiful opportunities for recharging during long hauls. Here we show that adding a single boxcar of battery equipment could enable battery-powered trains to achieve requisite operational ranges while surpassing the energy efficiency of diesel-electric trains.

Our analysis is based on a typical Class I train operating in California, with four 3.3-MW locomotives pulling 100 boxcars and 7,500 revenue-tons of weight. A typical boxcar has a rated load-carrying capacity of 103 tons, ${ }^{19}$ whereas heavy-duty freight cars with additional axles can carry up to 372 tons. $^{20}$

To calculate maximum range on one charge, we assume use of lithium ferrous phosphate (LFP) batteries in our base case, because they have a longer cycle life compared with nickel manganese cobalt (NMC) batteries and are more economical given the distances traveled by freight trains (1.5 million miles over 20 years). ${ }^{18}$ Assuming the current best energy density achieved by LFP batteries (which is lower than NMC energy density but still adequate for the rail sector), a single heavyduty boxcar could accommodate 44.5 MWh of storage, weighing 293 tons and occupying 4,560 cubic feet. This battery capacity is sufficient to power a representative train for approximately 425 
miles - much farther than existing estimates based on outdated battery energy densities that suggest a single tender car could carry only $6.2 \mathrm{MWh}^{21}$

A more realistic range requirement is 150 miles on a single charge, because the average U.S. Class I freight train travels this distance daily. ${ }^{7}$ The 150 -mile range requires a 14-MWh battery. Using cell-specific energy figures for LFP batteries and a typical packing fraction (cell weight/pack weight) of $0.8,{ }^{22}$ we estimate the total weight of a 14-MWh battery plus inverter at about 103 tons. By assuming the ratio of pack energy density $(\mathrm{kWh} / \mathrm{L})$ to pack specific energy $(\mathrm{kWh} / \mathrm{kg})$ is the same as at the cell level, we estimate a total battery volume of about 1,380 cubic feet. The combined volume of the battery ( 1,383 cubic feet) plus inverter ( 483 cubic feet) is about $40 \%$ of the estimated volume of a typical boxcar $(4,560$ cubic feet $) .{ }^{19}$ Hence, it is feasible on a weight and volume basis to achieve a 150-mile range using a single typical boxcar equipped with a 14-MWh battery and inverter. A range up to 425 miles could be achieved using a single heavy-duty boxcar before running up against volume constraints.

The energy consumed by battery freight trains increases by 5\% (150-mile range) to $14 \%$ (425-mile range) because of the additional battery weight, but it is still about half the energy consumed by diesel trains owing to the high efficiency of all-electric drives. We estimate that trains with a 150mile range (14-MWh battery) require approximately $0.050 \mathrm{kWh} /$ revenue-ton-mile with LFP technology and $0.046 \mathrm{kWh} /$ revenue-ton-mile with NMC technology. For comparison, an existing estimate of the energy requirements for battery-electric locomotives with regenerative braking is $0.02 \mathrm{kWh} /$ revenue-ton-mile. ${ }^{16}$

Battery-powered trains with at least 150 miles of range should have ample opportunity to charge during long routes while remaining on schedule. The average length of a Class I freight haul in the United States is 1,033 miles. ${ }^{3}$ The typical speed is $20-25$ miles per hour $(\mathrm{mph})$ between origin and destination, including all interruptions and stops. ${ }^{23}$ Based on the average daily distance of 150 miles and a maximum daily distance of at least 500 miles ( $25 \mathrm{mph}$ for 20 hours), typical freight trains should have opportunity to spend a few hours or more charging every day. Technological advances enable charging rates of 30 minutes to 1 hour for fully charging each cell (1C to $2 \mathrm{C}$ charging). Because charging speed is constrained at the cell level, the battery pack can theoretically be charged in 30 minutes to 1 hour. The ability to swap a discharged battery car with a charged battery car would provide additional flexibility. There appears to be significant downtime during which charged cars can be swapped with discharged cars; boxcars typically sit idle for up to 25 hours at a time. ${ }^{23}$

\section{Charging infrastructure costs}

37 The centralized and scheduled nature of freight rail operation and dispatch can enable high

38 utilization of fast-charging infrastructure, leading to lower costs. We estimate the cost of a 90-MW

39 charging station connected at the transmission level that charges 10 tender cars per day. Using 
1 historical prices from the Electric Reliability Council of Texas $\left(\right.$ ERCOT $\left.^{24}\right)$ and California 2 Independent System Operator $\left(\mathrm{CAISO}^{25}\right)$, we estimate the levelized cost of electricity plus 3 charging to be between $\$ 0.044 / \mathrm{kWh}(60 \%$ utilization, ERCOT) and $\$ 0.143 / \mathrm{kWh}(10 \%$ utilization, 4 CAISO) (Figure 1). Phadke et al. (2019) discuss the effect of rate designs on charging costs. ${ }^{26}$

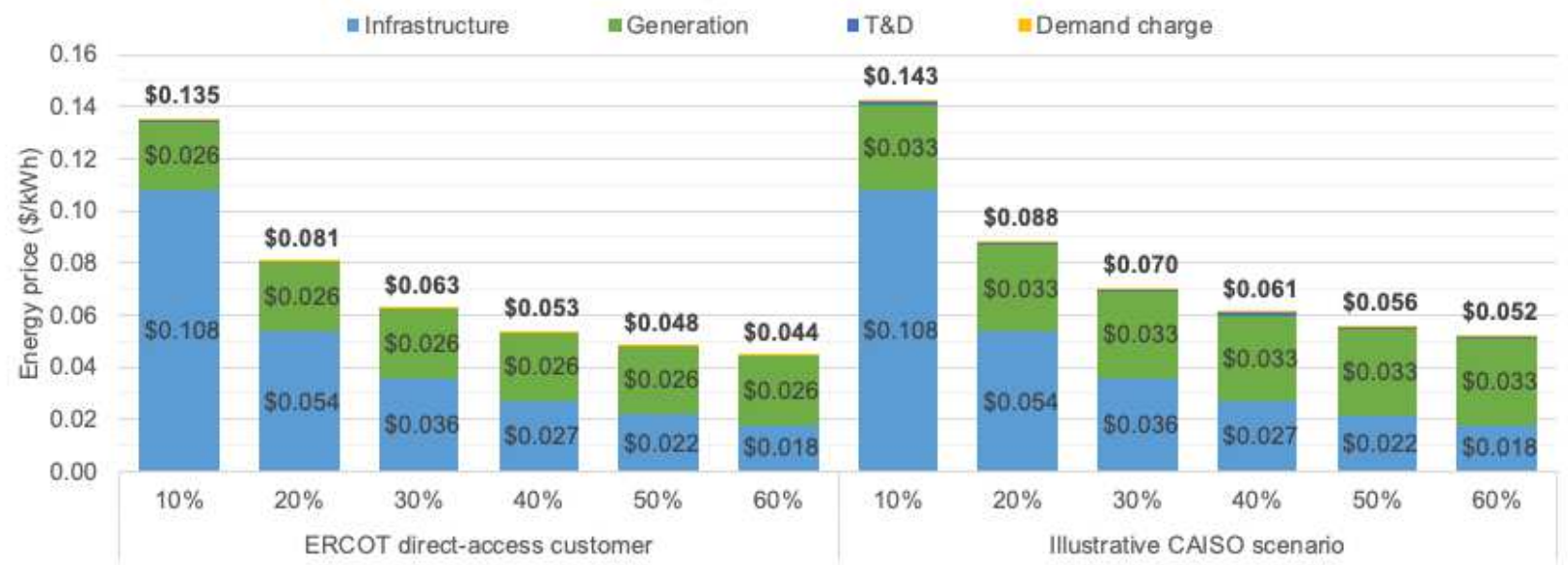

Figure 1. Energy prices $(\$ / \mathrm{kWh})$ inclusive of fast-charging infrastructure at various station utilization rates in ERCOT and CAISO. The ERCOT market assumes rail customers have access to wholesale prices. The illustrative CAISO market assumes ERCOT's critical peak pricing (CPP) rate structure and no resource adequacy surcharges. Baseline assumptions include an $80 \%$ depth of recharge, 10 tender cars per station, 1-hour charge time, $7 \%$ capital expenditure revenue return, ${ }^{27}$ and $10 \%$ efficiency losses in power conversion. Station lifetimes are estimated at 20 years. Generation prices are average hourly prices observed for each market for all hours 2017-2019.

\section{Grade capability}

14 Any vehicle's grade performance depends on its ability to increase power output. In an electric 15 powertrain, higher power outputs can be achieved by adding motors. Thus, delivering high peak power is much cheaper for an electric powertrain than for a diesel engine. For example, among freight truck powertrains, diesel engines cost about six times as much as an electric motor for an equivalent amount of power. ${ }^{28}$

\section{Achieving parity with diesel}

At near-future battery prices $(\$ 100 / \mathrm{kWh})$, battery-electric trains can achieve parity with dieselelectric trains if environmental costs are included or rail companies can access wholesale electricity prices and achieve $50 \%$ utilization of fast-charging infrastructure. If both conditions are achieved, fully electrifying the U.S. freight rail sector will lead to net savings of $\$ 250$ billion over 20 years.

The charging cost for a battery-electric train primarily includes the cost of the charging infrastructure and the cost of electricity. Cost of the charging infrastructure is mainly driven by its utilization factor, and we assume utilization of $50 \%$ is possible owing to centralized train scheduling and swappable battery cars. Electricity costs can be reduced by avoiding charging when 
1 electricity prices are high. In certain markets, such as ERCOT, demand and fixed transmission 2 charges can be avoided by avoiding charging during critical peak pricing (CPP) hours, which occur 3 during fewer than 50 hours per year. ${ }^{24}$ Average wholesale generation prices in key organized U.S. 4 markets for the last 3 years are less than 2 cents $/ \mathrm{kWh}$ during the lowest-priced $50 \%$ of hours in a 5 day. These prices are projected to decline even further with increasing renewable electricity 6 penetration.

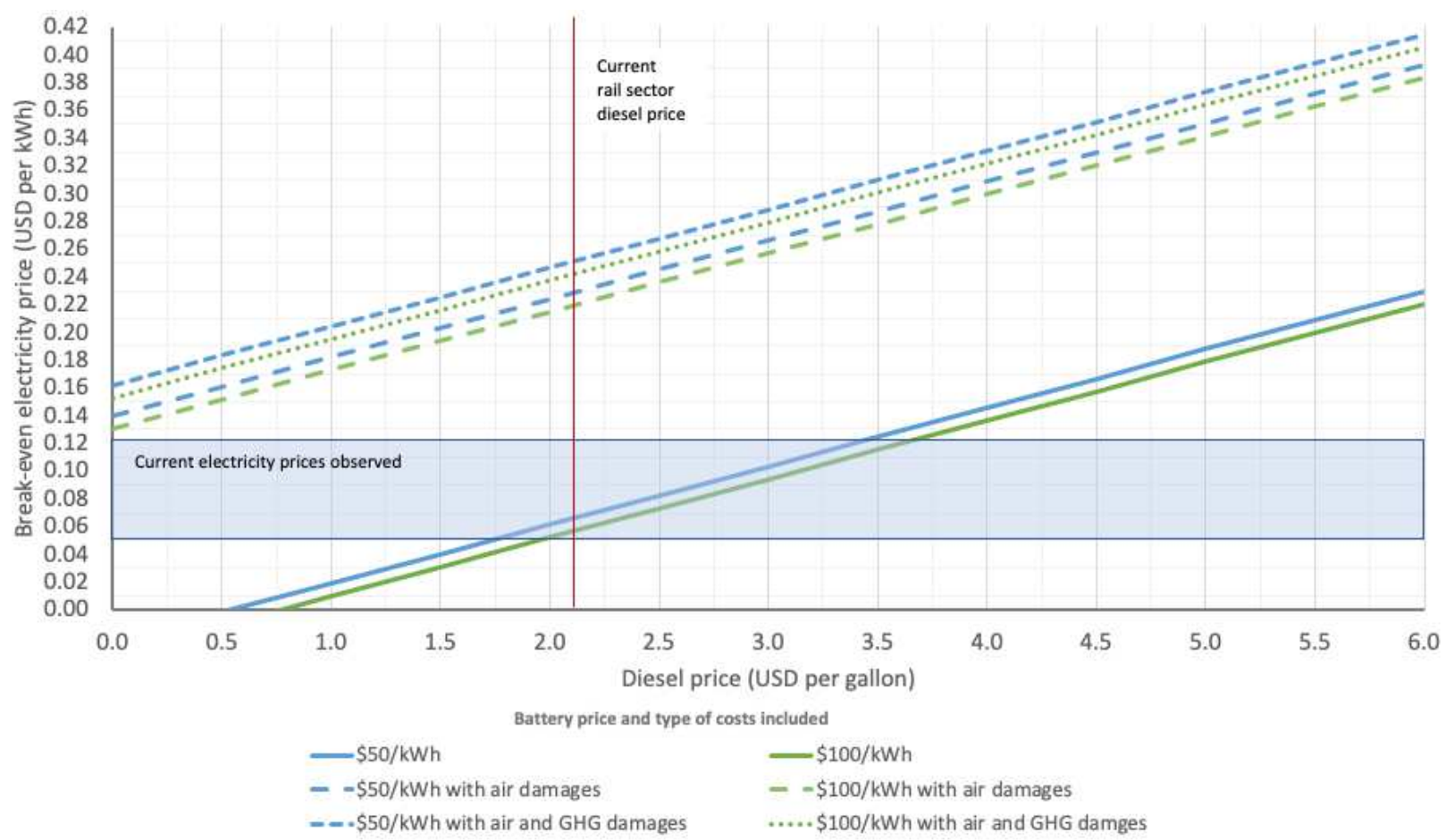

Figure 2. All-inclusive electricity prices (electricity cost plus charging-infrastructure cost) needed to reach diesel parity based on total cost of ownership (TCO), assuming near-term and projected battery prices with LFP technology over a 20-year horizon. The solid lines do not include environmental damages, the dashed lines include criteria air pollutant damages only, and dotted lines include damages from both criteria air pollutants and GHG emissions. At current wholesale diesel prices of $\$ 2.12 /$ gallon and ignoring environmental damages, all-inclusive electricity prices would need to approach $\$ 0.057 / \mathrm{kWh}$ with battery prices at $\$ 100 / \mathrm{kWh}$ and $\$ 0.066 / \mathrm{kWh}$ with battery prices at $\$ 50 / \mathrm{kWh}$ to compete with diesel. These estimates are based on a locomotive with a 150-mile range pulling 1,211 revenue-tons with TCO annualized over a 20 -year horizon and 3\% discount rate. Environmental savings are estimated using $100 \%$ renewable electricity generation.

Using the energy requirement of $0.050 \mathrm{kWh} /$ revenue-ton-mile for LFP batteries, we estimate electricity prices necessary to achieve parity with diesel for a battery-powered train with a 150mile range pulling 1,211 revenue-tons. To do so, we estimate the capital cost of required battery capacity and the associated cost of charging, inclusive of the battery weight, cooling requirements, and inverter. Figure 2 depicts the relationships among battery prices, diesel prices, and electricity prices needed to motivate a switch to battery-powered trains. To achieve parity with diesel prices reported by the rail industry (averaging $\$ 2.12 /$ gallon $^{29}$ ), all-inclusive electricity prices (electricity generation plus amortized charging costs) must reach $\$ 0.057 / \mathrm{kWh}$ with near-future LFP 
1 technology priced at $\$ 100 / \mathrm{kWh}$; this calculation excludes environmental costs. If major markets

2 followed tariff rules like ERCOT's CPP structure, rail freight companies could realize electricity 3 costs (including charging-infrastructure costs) $\$ 0.057 / \mathrm{kWh}$ if they reach $35 \%$ utilization of fast-

4 charging infrastructure - thus achieving parity with diesel-powered trains.

\section{Sector-wide cost savings}

7 Here we investigate the net present value (NPV) over 20 years to the freight rail sector of 8 converting diesel-electric locomotives into battery-electric, comparing the capital and operating 9 costs along with costs of damages from $\mathrm{CO}_{2}$ and criteria air pollutants. We use a diesel price of $10 \$ 2.12 /$ gallon in each scenario. The NPV of switching to battery-electric trains ranges from a cost 11 of $\$ 17$ billion in the baseline scenario (25\% station utilization) to savings of $\$ 250$ billion in the 12 low tariff scenario (50\% station utilization) plus consideration of environmental damages with $13 \quad 100 \%$ renewable electricity use (Figure 3 ). When the NPV is positive, payback periods range from 1411 years to just over 1 year per locomotive. Switching to battery-electric propulsion reduces annual $15 \mathrm{CO}_{2}$ emissions in the freight rail sector by 6.9 million metric tons using the U.S. power mix, 19.6 16 million metric tons with the California power mix, and 37.3 million metrics tons with $100 \%$ 17 renewable electricity, from a baseline of 37.3 million metric tons. Without taking environmental 18 costs into account, the main determinants of the economic returns are the all-inclusive electricity price and the price of diesel fuel. Low battery prices $(\$ 50 / \mathrm{kWh})$ alone are not sufficient to achieve sector-wide payback over 20 years. Even a modest price on the external environmental damages,

21 equivalent to less than $\$ 0.30$ /gallon of diesel, would be sufficient to make battery-electric cost22 competitive with diesel-electric locomotives at a near-future battery price $(\$ 100 / \mathrm{kWh})$ and current 23 electricity-plus-charging-infrastructure prices $(\$ 0.070 / \mathrm{kWh})$. 


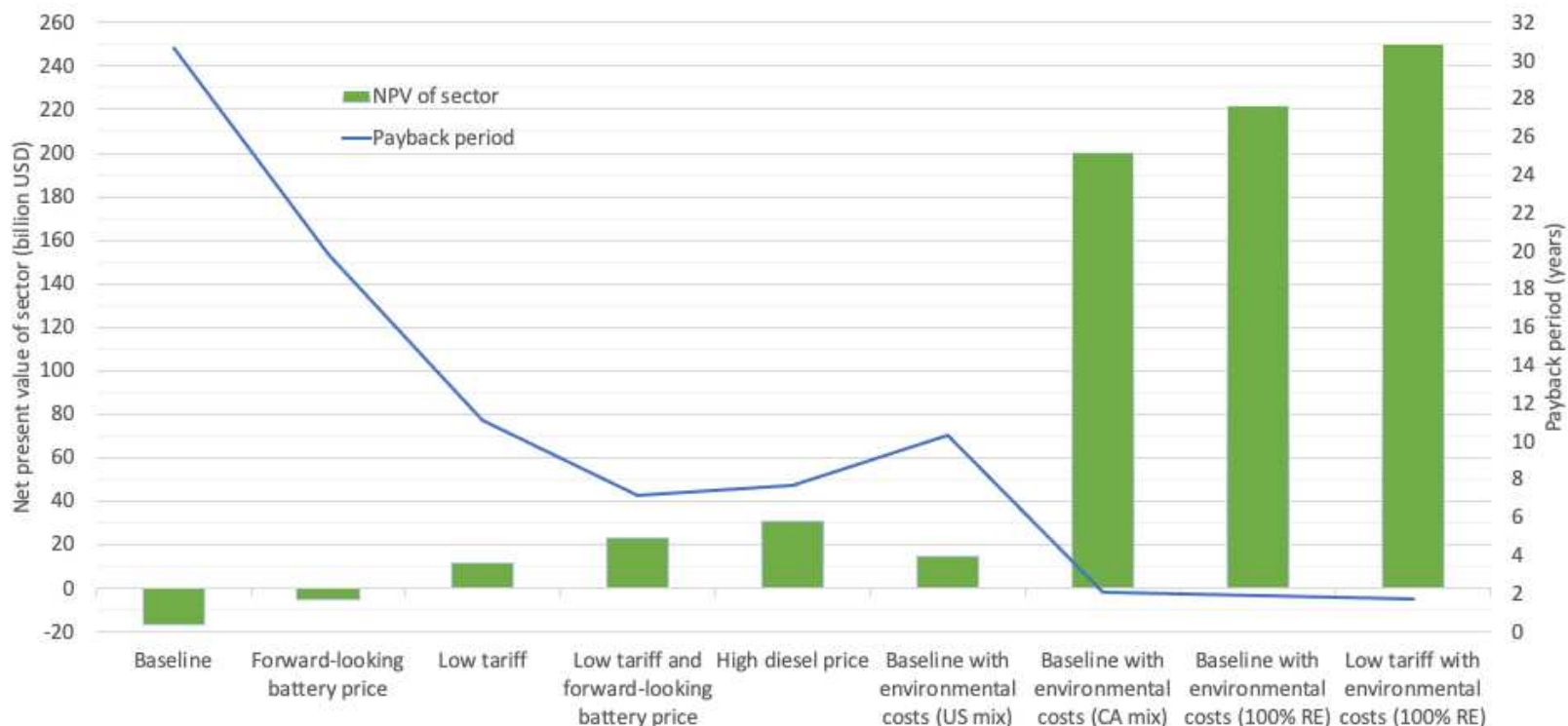

Figure 3. NPV of savings over 20 years for the U.S. freight rail sector. The line corresponds to the right $y$-axis and represents the payback period per locomotive in years. The columns correspond to the left $y$-axis and represent the NPV of the rail sector using LFP battery technology. All scenarios are based on a 150-mile range for a 3.3-MW locomotive pulling 1,211 revenue-tons. The baseline scenario assumes a $\$ 2.12 /$ gallon diesel price, $\$ 100 / \mathrm{kWh}$ battery price, $\$ 0.070 / \mathrm{kWh}$ electricity-plus-charging-infrastructure price (assumes $25 \%$ station utilization rate), and $3 \%$ discount rate. The forward-looking battery price is $\$ 50 / \mathrm{kWh}$. Break-even sector NPV occurs at station utilization rates of $35 \%$, with tariffs at $\$ 0.057 / \mathrm{kWh}$. The low electricity tariff inclusive of fast-charging infrastructure is $\$ 0.048 / \mathrm{kWh}$ (assumes 50\% station utilization rate). The high diesel scenario uses the baseline case with a $\$ 3 / g a l l o n$ diesel price. Environmental savings are added to the baseline case and are estimated using U.S., California, and $100 \%$ renewable electricity mixes.

Value of modular and mobile storage to the power system

A battery-electric rail sector will have nearly $240 \mathrm{GWh}$ of modular and mobile storage, providing four advantages over typical grid-scale storage or storage in automotive electric vehicles (EVs). First, locomotives will still have their diesel engines, so their batteries can be available to the power system to manage extreme events. This is not the case with typical EVs, which do not have dualfuel capabilities. Second, unlike typical grid-scale storage, a train can be moved to address location-specific power system constraints. Third, because the batteries sit on railcars, which can be attached or detached from freight trains seamlessly, they can be flexibly deployed to charge and discharge in optimal locations - charging where prices are low and discharging where the grid is most constrained. Fourth, the four major players in the freight rail industry have maintained a market share of about $85 \%,{ }^{30}$ and each could control large amounts of mobile energy storage, in contrast to fragmented storage ownership that requires highly efficient markets for optimal use. Large-scale modular and mobile storage from trains could support the power system in several ways with appropriate vehicle-to-grid infrastructure, including supplying power to the grid during extreme price or demand events, supporting temporary decommissioning of the transmission and distribution (T\&D) infrastructure during wildfire events, and providing emergency backup power 
to critical loads in the case of outages. Further research is needed to evaluate such possibilities as well as enabling infrastructure and policy.

\section{Comparison with electrification via catenary}

5 At the global level, the International Energy Agency compares levelized operating costs per mile for electric-catenary and battery-electric locomotives. Based on this analysis, 9.9-MW batteryelectric trains cost \$19.3/train-mile (248-mile range) and \$27/train-mile (466-mile range), and electric-catenary trains cost about $\$ 16 /$ train-mile, not including the capital cost of electric infrastructure. ${ }^{2}$ These estimates represent upper bounds for battery-electric trains, because they assume a battery price of $\$ 250 / \mathrm{kWh}$ (almost double current battery prices) and an electricity price of $\$ 0.17 / \mathrm{kWh}$, three times higher than prices already seen for long-term power-purchasing agreements in California. ${ }^{26}$

Although electrification via catenary is widespread in Europe and Asia, the context is not directly transferable, because U.S. locomotive power requirements are approximately 10 times greater than requirements in Europe, dramatically increasing the average costs per mile. ${ }^{21}$ Furthermore, the frequent use of double-stack containers in the United States makes catenary requirements problematic; infrastructure would need to be 23.5 feet higher than the tracks to accommodate such trains. ${ }^{21}$ In the United States, costs for catenary construction range from $\$ 8.3 \mathrm{million} / \mathrm{mile}^{31}$ to $\$ 50$ million/mile, ${ }^{16}$ excluding the cost of the locomotives. One advantage of battery-electric diesel locomotives is that batteries could simply be attached to existing locomotives with an extra tender car, rather than purchasing new locomotives or upgrading tracks.

\section{Discussion}

Our analysis provides initial evidence that switching from diesel-electric to battery-electric locomotives could save the U.S. freight rail sector billions of dollars while yielding environmental, health, and grid-resilience benefits. Retrofitting existing diesel-electric locomotives with battery tender cars is a cost-effective technology for transitioning to a zero-emissions rail sector with nearfuture battery prices and access to wholesale electricity tariffs. In the United States, this approach to freight train electrification is especially attractive, because using a catenary system is much more expensive than in other countries. Other countries also rely heavily on diesel-electric locomotives (e.g. China, Russa, India, and Canada). ${ }^{2}$ Even locations with electrified rail could stand to benefit from mobile grid storage provided by battery tender cars if they experience locationally-constrained grid stress.

Wholesale U.S. renewable electricity prices have dropped to about $1.5-3$ cents $/ \mathrm{kWh}$, less than half the long-run marginal cost of electricity from fossil fuel plants. ${ }^{15}$ Current electricity-mix emissions intensities are $844 \mathrm{lb} \mathrm{CO}_{2} / \mathrm{MWh}$ nationwide ${ }^{32}$ and $491 \mathrm{lb} \mathrm{CO}_{2} / \mathrm{MWh}$ in California. ${ }^{33}$ However, because battery cars can charge predominantly when renewable electricity is available, they can exploit low-cost, zero-emission energy. The ability of tariff policies such as real-time pricing to 
enable use of low-cost renewable electricity for battery-electric trains must be evaluated further.

To achieve diesel parity in the short run, such low-cost tariffs are necessary.

Although they are highly fuel efficient, diesel locomotives generate 1.7 times more air pollution damage per gallon of diesel than diesel trucks do, causing about 1,500 premature deaths every year and accounting for $\$ 14.1$ billion in health damage costs. ${ }^{6}$ Our analysis shows that battery-electric trains are cost-effective today if diesel-electric trains internalize the costs of these damages. A commensurate air pollution damage charge or strict air pollution standards that minimize these damages could enable a transition toward battery-electric trains. Such policy options must be evaluated in more detail.

Although we estimate battery sizes for typical daily freight train ranges, even much smaller batteries can substantially mitigate air pollution damages. Assuming most damages result from the concentration of populations around railyards, train operators may wish to add just enough capacity to run trains on battery power in these areas. BNSF is currently pursuing this approach as part of a project funded by the California Air Resources Board to reduce emissions around railyards ${ }^{34}$ Furthermore, although it is feasible to achieve ranges up to 425 miles with a single battery tender car, payload capacity on certain U.S. rail segments, such as bridges, is limited to 134 tons per car. ${ }^{35}$ In light of such constraints, it may make more sense to forego additional revenue-tons by adding extra battery tender cars rather than increasing the maximum range for a single car. Further research could provide insight into optimal ranges for different trip lengths and locations.

Lastly, planning and deploying a bidirectional charging infrastructure to optimize grid services via charging and discharging of battery-electric cars will be required to capture the full economic and environmental value of battery-electric trains. Further research is needed on the deployment and operation of such infrastructure.

\section{Methods}

We estimate the levelized cost of ownership to convert the U.S. freight rail sector from diesel to battery-electric locomotives in dollars per revenue-ton-mile. We consider scenarios that progressively improve the case for battery-electric locomotives. We begin with a baseline scenario of average charging costs (which capture both electricity tariffs and costs of installing fastcharging infrastructure), no consideration of environmental benefits, and no further decline in battery prices. This scenario represents the economics without any policy intervention in approximately the year 2023. We then consider scenarios of low charging costs (reflecting cases in which low-cost renewable electricity can be used), further declines in battery prices as projected by most analyses, and inclusion of the value of environmental benefits. Low renewable electricity prices can be achieved by implementing policies such as real-time pricing, with tariffs linked to wholesale market prices, and environmental regulations that capture the economic value of 
1 environmental benefits. ${ }^{26}$ Such prices are already observed, for example, in California during 2 certain times of the day. The main departure from previous estimates are the dramatic increases in

3 battery energy densities coupled with recent and ongoing decreases in battery prices.

\section{Scenario}

6 The key baseline input parameters used in this analysis, which represent current and near-term 7 forecasted technology and prices (in 2019 U.S. dollars), are listed in Table 1. We estimate battery 8 size based on the specifications of trains currently operating in California, representative of line9 haul trains consisting of four 3.3-MW locomotives carrying 7,500 revenue-tons. ${ }^{16}$

\section{Table 1. Baseline assumptions for typical U.S. train}

\section{Train characteristics}

\begin{tabular}{|c|c|c|}
\hline Power rating of locomotive ${ }^{16}$ & 3.3 & MW \\
\hline Power rating of train (4 locomotives) & 13.2 & MW \\
\hline Train pull weight ${ }^{16}$ & 7,500 & revenue-tons \\
\hline Locomotive pull weight & 1,875 & revenue-tons \\
\hline Efficiency of diesel engine $^{16}$ & 0.39 & \\
\hline Energy intensity of freight rail sector & 293 & BTU/ton-mile \\
\hline Energy requirements for diesel-powered train ${ }^{16}$ & 0.086 & $\mathrm{kWh} /$ ton-mile \\
\hline Range & 150 & miles \\
\hline Volume of 48 -foot boxcar ${ }^{19}$ & 4,560 & cubic feet \\
\hline Payload capacity of standard boxcar ${ }^{19}$ & 103 & tons \\
\hline
\end{tabular}

\section{Battery size}

14 We estimate necessary battery size using bottom-up calculations for the representative train. Using 15 the average energy requirements of the diesel baseline at $0.086 \mathrm{kWh} /$ ton-mile, and the relative 16 efficiency of battery power over diesel engines, we estimate that each locomotive requires a battery 17 of 14 MWh using LFP technology to pull 1,875 revenue-tons for 150 miles. Table 2 describes the 18 input parameters for determining battery pack size. 


\begin{tabular}{|c|c|c|c|}
\hline \multicolumn{4}{|c|}{ Energy requirements for battery-powered train } \\
\hline Heat value of diesel ${ }^{36}$ & \multicolumn{2}{|r|}{10.6} & $\mathrm{kWh} / \mathrm{L}$ \\
\hline Battery pack assumptions & $N M C$ & $L F P$ & \\
\hline Cell specific energy ${ }^{37}$ & 0.308 & 0.21 & $\mathrm{kWh} / \mathrm{kg}$ \\
\hline Packing fraction ${ }^{22}$ & 0.8 & 0.8 & \\
\hline Cell energy density ${ }^{37}$ & 0.754 & 0.47 & $\mathrm{kWh} / \mathrm{L}$ \\
\hline Battery roundtrip efficiency ${ }^{38}$ & 0.9 & 0.95 & \\
\hline Efficiency relative to diesel & 2.31 & 2.44 & \\
\hline Depth of discharge ${ }^{39}$ & 0.9 & 0.8 & \\
\hline \multicolumn{4}{|l|}{ Cooling requirements } \\
\hline Battery tender car floor area & & 567 & square feet \\
\hline Temperature change & & 15 & degrees Celsius \\
\hline Operating time & & 12 & hours per day \\
\hline Cooling load & & 9,000 & BTU/hour \\
\hline
\end{tabular}

3 We estimate battery size using LFP technology, which has a lower energy density but longer 4 lifetime than NMC technology. In the rail sector, the opportunity costs of larger batteries are 5 significantly lower than in the trucking sector. Batteries incur an efficiency loss due to the need to 6 cool the battery system. We upsize the battery to accommodate air conditioning requirements for 7 the battery tender car. We estimate the energy required to cool the entire volume of the boxcar by $8 \quad 15^{\circ} \mathrm{C}$ over 12 hours of the day. We assume that the locomotive still has its existing diesel engine 9 and fuel tank.

\section{Charging cost}

12 We adapt the method from previous research on TCO for electrifying the trucking sector ${ }^{26}$ to the 13 rail sector, estimating the unit cost of charging as the total of the levelized cost of equipment, the 14 cost of generation, and the cost of T\&D. Table 3 describes the inputs used to estimate unit charging 15 costs for the ERCOT market. Following their method, ${ }^{26}$ we model the unit charging cost for a retail 16 customer who is able to access wholesale energy prices in ERCOT territory. This scenario is 17 realistic under current regulations. The levelized cost of equipment, in this scenario, is defined as 18 the minimum price per unit of energy delivered $(\mathrm{kWh})$ that a charging service provider should 19 charge the consumer to break even on the investment in charging equipment and grid 20 interconnection. $^{26}$ 
Table 3. Input parameters for levelized unit charging costs in existing ERCOT and illustrative

2 CAISO market

\begin{tabular}{|c|c|c|c|c|c|}
\hline $\begin{array}{l}\text { Cost } \\
\text { component }\end{array}$ & Description & Cost & Description & Cost & Units \\
\hline & \multicolumn{2}{|l|}{$\begin{array}{r}\text { ERCOT } \\
\end{array}$} & \multicolumn{2}{|l|}{ CAISO } & \\
\hline $\begin{array}{l}\text { Electricity } \\
\text { generation }\end{array}$ & $\begin{array}{l}\text { Price a retail electric } \\
\text { provider would pay to pass } \\
\text { through the real-time price } \\
\text { to a retail customer, based } \\
\text { on ERCOT prices } 2017- \\
2019^{24} \text { and ERCOT day- } \\
\text { ahead market clearing } \\
\text { prices for capacity }{ }^{40}\end{array}$ & 26.3 & $\begin{array}{l}\text { Illustratively modeled as the price an } \\
\text { energy service provider would pay to } \\
\text { pass through the real-time price to a } \\
\text { direct-access customer, not including } \\
\text { resource adequacy payments, based on } \\
\text { CAISO real-time prices } 2017-2019,25 \\
\text { CA renewable portfolio standards, }{ }^{41} \\
\text { REC prices }{ }^{42} \text {, and CAISO fees }\end{array}$ & 32.9 & $\$ / \mathrm{MWh}$ \\
\hline $\begin{array}{l}\text { Transmission } \\
\text { and } \\
\text { distribution }\end{array}$ & $\begin{array}{l}\text { T\&D charges paid by a } \\
\text { transmission-connected } \\
\text { customer in Oncor service } \\
\text { territory, charging only at } \\
\text { non-critical-peak times }{ }^{44}\end{array}$ & 0.3 & $\begin{array}{l}\text { T\&D charges paid by a transmission- } \\
\text { connected customer in Oncor service } \\
\text { territory, charging only at non-critical- } \\
\text { peak times }\end{array}$ & 0.3 & $\$ / \mathrm{MWh}$ \\
\hline $\begin{array}{l}\text { Electrical } \\
\text { equipment }\end{array}$ & \multicolumn{3}{|c|}{$\begin{array}{l}\text { Average of best-case electric vehicle supply equipment (EVSE) costs, taken to } \\
\text { be (1) the balance of system (BOS) costs of grid-tied storage, and ( } 2 \text { ) industry- } \\
\text { projected EVSE costs, based on utility-scale solar + storage BOS costs }{ }^{45} \text { and } \\
\text { inverter lifetime }\end{array}$} & 18.2 & $\$ / \mathrm{MWh}$ \\
\hline $\begin{array}{l}\text { Grid } \\
\text { connection }\end{array}$ & \multicolumn{3}{|c|}{$\begin{array}{l}\text { Average U.S. grid connection cost for utility-scale solar photovoltaic (PV) } \\
\text { projects }^{47}\end{array}$} & 5.5 & $\$ / M W h$ \\
\hline $\begin{array}{l}\text { Operations } \\
\text { and } \\
\text { maintenance }\end{array}$ & \multicolumn{3}{|c|}{$\begin{array}{l}\text { Cost of (1) inverter maintenance for a PV plant, (2) preventive maintenance } \\
\text { and inspection, averaged for both an existing electric bus charging station and } \\
\text { the electrical/wiring inspection costs of a PV plant, and (3) estimated structural } \\
\text { maintenance }\end{array}$} & 4.8 & $\$ / \mathrm{MWh}$ \\
\hline Installation & \multicolumn{3}{|c|}{$\begin{array}{l}\text { Installation costs associated with grid-tied storage, grid-connected storage cost } \\
\text { of installation, labor, and equipment, EPC overhead, and interconnection }{ }^{45}\end{array}$} & 7.5 & $\$ / \mathrm{MWh}$ \\
\hline Capital & \multicolumn{3}{|c|}{$\begin{array}{l}\text { Return owed on capital investment, based on California Investor Owned } \\
\text { Utilities (IOU) rates of return }{ }^{27}\end{array}$} & 7 & $\%$ \\
\hline
\end{tabular}

Table 4 reports the historical and projected wholesale energy price patterns for two energy markets. We estimate the percentage of hours observed under a specific price point as the average hourly wholesale price observed for all days in the timeframe. Already, the 12 cheapest hours of the day in both markets are below \$23/MWh (used for the base case in the NPV calculations). Combined with a $35 \%$ charging station utilization rate, battery-electric locomotives can achieve parity with diesel-electric locomotives. 
Table 4. Historical wholesale energy prices in ERCOT and CAISO

\begin{tabular}{lll}
\hline & \multicolumn{2}{c}{ Historical (2017-2019) } \\
\cline { 2 - 3 } & CAISO $^{25}$ & ERCOT $^{24}$ \\
\hline \% of hours under \$30/MWh & 60 & 76 \\
\% of hours under \$45/MWh & 87 & 91 \\
Avg. price of 8 cheapest hours of the day (\$/MWh) & 17.5 & 16.9 \\
Avg. price of 12 cheapest hours of the day (\$/MWh) & 20.3 & 18.4 \\
Avg. price of 8 cheapest hours on the most expensive day (\$/MWh) & 69.4 & 44.3 \\
\hline Note: These prices reflect only the price of generation, and do not include fast-charging infrastructure, T\&D, or \\
demand charges
\end{tabular}

\section{Sector-wide cost of ownership}

12 We use a straightforward energy balance approach using national data on train revenue-ton-miles and diesel fuel consumption to estimate the approximate energy requirements to transport the same tonnage under battery-electric propulsion. To ensure that our sector-wide results do not overestimate electricity requirements, we use the national average estimates to calculate sectoral costs, benefits, and emissions. Whereas a representative line-haul locomotive may pull 1,875 revenue-tons, the national average Class I freight locomotive travels 150 miles per day and carries only 1,211 revenue-tons. Our estimates suggest that this load requires about a 9.1-MWh battery per locomotive, after adjusting for battery weight and cooling requirements.

Each locomotive with an $\mathrm{AC}$ traction motor requires an onboard inverter for the 3.3-MW traction motor at $\$ 70 / \mathrm{kWh}^{45}$ Table 5 lists the key baseline input parameters used in this analysis, which represent current and near-term forecasted prices. We borrow existing methods to estimate charging costs that include electricity and fast-charging infrastructure costs, where the equipment cost per $\mathrm{kWh}$ decreases as a function of capacity utilization. Assuming a capacity utilization rate of $50 \%$ (train batteries are charging for approximately 12 of 24 hours each day) amortized fastcharging infrastructure costs plus energy are $\$ 0.048 / \mathrm{kWh}$. We estimate a low-cost scenario of $\$ 0.048 / \mathrm{kWh}(50 \%$ capacity utilization) and a high-cost scenario of $\$ 0.07 / \mathrm{kWh}(25 \%$ capacity utilization) inclusive of the levelized cost of fast-charging infrastructure. Given the flexibility in charging times, we would expect that train operators would have access to the lowest energy prices. 
1 We calculate environmental impacts by comparing diesel emissions to baseline emissions from

2 electricity generation using three different power mixes: the U.S. average, the California power

3 mix, and $100 \%$ renewables.

4

$5 \quad$ Table 5. Input parameters for TCO model

\begin{tabular}{|c|c|c|}
\hline \multicolumn{3}{|l|}{ Unit capital cost components } \\
\hline Battery life ${ }^{a}$ & $\begin{array}{l}2,000- \\
4,000\end{array}$ & cycles \\
\hline Cost of battery $^{13}$ & $50-100$ & $\$ / \mathrm{kWh}$ \\
\hline Cost to replace battery & 50 & $\$ / \mathrm{kWh}$ \\
\hline Cost of inverter ${ }^{45}$ & 70 & $\$ / \mathrm{kWh}$ \\
\hline Cost of standard boxcar ${ }^{48}$ & 135,000 & $\$$ \\
\hline Inverter size & 3.3 & MW \\
\hline \multicolumn{3}{|l|}{ Unit fuel cost components } \\
\hline Electricity price (inclusive of fast-charging infrastructure) & $\begin{array}{l}0.048- \\
0.070\end{array}$ & $\$ / \mathrm{kWh}$ \\
\hline Cycles per day & 1 & \\
\hline Diesel price ${ }^{29}$ & $2.12-3$ & $\$ /$ gal \\
\hline Avg. fuel consumption per locomotive per day ${ }^{18}$ & 384 & gallons \\
\hline \multicolumn{3}{|l|}{ Unit air pollution costs } \\
\hline Air pollution damages per diesel locomotive ${ }^{6}$ & 1,458 & $\$ /$ day \\
\hline Damages of locomotive sector across all air pollutants ${ }^{6}$ & 14.1 & billion $\$$ \\
\hline Air pollution damages from coal-based electricity generation ${ }^{6}$ & 135 & billion \$/year \\
\hline Air pollution damages from gas-based electricity generation 6 & 5.55 & billion $\$ /$ year \\
\hline Coal-fired generation $(2019)^{49}$ & 966 & billion MWh/year \\
\hline Gas-fired generation ${ }^{49}$ & 1,582 & billion $\mathrm{MWh} /$ year \\
\hline \multicolumn{3}{|l|}{ Unit GHG emissions cost components } \\
\hline Marginal damage of $\mathrm{CO}_{2}$ emissions $^{50}$ & 52 & $\$ /$ metric ton $\mathrm{CO}_{2}$ \\
\hline Diesel to $\mathrm{CO}_{2}$ conversion factor ${ }^{51}$ & 10.21 & $\mathrm{~kg} \mathrm{CO}_{2} / \mathrm{gal}$ \\
\hline Emissions intensity of coal-fired electricity ${ }^{52,53}$ & 210.4 & $\mathrm{lb} \mathrm{CO} /$ million BTU \\
\hline Emissions intensity from gas-fired electricity ${ }^{52}$ & 117 & $\mathrm{lb} \mathrm{CO}_{2} /$ million BTU \\
\hline Emissions intensity of U.S. power mix ${ }^{32}$ & 844 & $\mathrm{lb} \mathrm{CO} / \mathrm{MWh}$ \\
\hline Emissions intensity of California power mix $^{33}$ & 491 & $\mathrm{lb} \mathrm{CO} / \mathrm{MWh}$ \\
\hline
\end{tabular}

6

7

8

9

10

11

12

\section{Data availability}

The data that support the results of this study are available from the corresponding author upon request.

\section{References}


1. Masson-Delmotte, V. et al. IPCC Special Report: Global Warming of $1.5^{\circ}$ C. Ipcc - Sr15 (2018).

2. International Energy Agency. The Future of Rail - Opportunities for energy and the environment. (2019). doi:https://doi.org/10.1787/9789264312821-en

3. Davis, S. C. \& Boundy, R. G. Transportation Energy Data Book. (2020). doi:10.1146/annurev.energy.14.1.375

4. Association of American Railroads. Freight Rail \& Preserving the Environment. Available at: https://www.aar.org/issue/freight-rail-and-the-environment/. (Accessed: 11th December 2020)

5. Liu, L. et al. Emission Projections for Long-Haul Freight Trucks and Rail in the United States through 2050. Environ. Sci. Technol. 49, 11569-11576 (2015).

6. Goodkind, A. L., Tessum, C. W., Coggins, J. S., Hill, J. D. \& Marshall, J. D. Fine-scale damage estimates of particulate matter air pollution reveal opportunities for location-specific mitigation of emissions. Proc. Natl. Acad. Sci. U. S. A. 116, 8775-8780 (2019).

7. U.S. Department of Transportation Bureau of Transportation Statistics. National Transportation Statistics. (2018).

8. U.S. Environmental Protection Agency. Regulations for Emissions from Heavy Equipment with Compression-Ignition (Diesel) Engines. Available at: https://www.epa.gov/regulations-emissionsvehicles-and-engines/regulations-emissions-heavy-equipment-compression. (Accessed: 11th December 2020)

9. Caltrain. Caltrain Modernization Program Peninsula Corridor Electrification Project January 2019 Monthly Progress Report. (2019).

10. Bogdanov, D. et al. Radical transformation pathway towards sustainable electricity via evolutionary steps. Nat. Commun. 10, 1-16 (2019).

11. Field, K. BloombergNEF: Lithium-Ion Battery Cell Densities Have Almost Tripled Since 2010. CleanTechnica (2020).

12. Randall, T. \& Warren, H. Peak Oil Is Suddenly Upon Us. Bloomberg (2020). Available at: https://www.bloomberg.com/graphics/2020-peak-oil-era-is-suddenly-upon-us/. (Accessed: 14th December 2020)

13. BloombergNEF. Battery Pack Prices Fall As Market Ramps Up With Market Average At $\$ 156 / \mathrm{kWh}$ In 2019. BNEF (2019).

14. Walton, R. Electric vehicle models expected to triple in 4 years as declining battery costs boost adoption | Utility Dive. Utility Dive (2020).

15. Lazard. Lazard's levelized cost of energy analysis-version13.0. (2019).

16. Rail Transportion and Engineering Center. Transitioning to a Zero or Near-Zero Emission LineHaul Freight Rail System in California: Operational and Economic Considerations. (2016).

17. U.S. Department of Transportation Bureau of Transportation Statistics. Truck Profile. (2020). Available at: https://www.bts.gov/content/truck-profile. (Accessed: 14th December 2020)

18. Bureau of Transportation Statistics. Table 4-17: Class I Rail Freight Fuel Consumption and Travel. Available at: https://www.bts.gov/archive/publications/national_transportation_statistics/table_04_17. (Accessed: 14th December 2020)

19. BNSF Railway. Boxcars. Available at: https://www.bnsf.com/ship-with-bnsf/ways-ofshipping/equipment/boxcars.html. (Accessed: 14th December 2020)

20. Kasgro Rail Corporation. Equipment List. Available at: http://www.kasgro.com/equipment.html. (Accessed: 10th December 2020)

21. California Air Resources Board. Technology Assessment: Freight Locomotives. (2016).

22. Phadke, A., Khandekar, A., McCall, M., Karali, N. \& Rajagopal, D. Long-haul battery electric trucks are technically feasible and economically compelling. LBNL Work. Pap. 1-17 (2019).

23. Union Pacific Corporation. United States Securities and Exchange Commission Form 10-K. (2020).

24. Electric Reliability Council of Texas. Historical RTM Load Zone and Hub Prices. Available at: http://mis.ercot.com/misapp/GetReports.do?reportTypeId=13061\&reportTitle=Historical RTM 
Load Zone and Hub Prices\&showHTMLView=\&mimicKey. (Accessed: 14th December 2020)

25. LCG Consulting. CAISO (California ISO): Real-time Price. Energy Online Available at: http://www.energyonline.com/Data/GenericData.aspx?DataId=19\&CAISO__Real-time_Price. (Accessed: 14th December 2020)

26. Phadke, A., McCall, M. \& Rajagopal, D. Reforming electricity rates to enable economically competitive electric trucking. Environ. Res. Lett. 14, (2019).

27. California Public Utilities Commission. Rate of Return (ROR) (Actual and Authorized). Available at: https://www.cpuc.ca.gov/General.aspx?id=12093. (Accessed: 15th December 2020)

28. Sripad, S. \& Viswanathan, V. Quantifying the Economic Case for Electric Semi-Trucks. ACS Energy Lett. 4, 149-155 (2019).

29. Surface Transportation Board. Annual Report Financial Data. Available at: https://prod.stb.gov/reports-data/economic-data/annual-report-financial-data/. (Accessed: 14th December 2020)

30. Mazareanu, E. Leading North American railroads in 2019, based on operating revenue. Statistica (2020). Available at: https://www.statista.com/statistics/271613/leading-north-american-railroadcompanies-based-on-revenue/. (Accessed: 14th December 2020)

31. Caltrain. Peninsula Corridor Joint Powers Board Staff Report. (2019).

32. Carnegie Mellon University. U.S. Power Sector CO2 Emissions Intensity. Available at: https://emissionsindex.org/. (Accessed: 14th December 2020)

33. U.S. Energy Information Administration. California Electricity Profile 2018. Available at: https://www.eia.gov/electricity/state/archive/2018/california/. (Accessed: 15th May 2020)

34. Business Wire. BNSF Awarded \$22.6 Million State Grant for Clean Technology Pilot Program. (2018). Available at: https://www.businesswire.com/news/home/20181011005675/en/. (Accessed: 14th December 2020)

35. Union Pacific Corporation. Allowable Gross Weight Shipments. Available at: https://www.up.com/aboutup/reference/maps/allowable_gross_weight/index.htm. (Accessed: 14th December 2020)

36. U.S. Energy Information Administration. Energy conversion calculators. Available at: https://www.eia.gov/energyexplained/units-and-calculators/energy-conversioncalculators.php\#dieselcalc. (Accessed: 14th December 2020)

37. Argonne National Laboratory. BatPaC: Battery Manufacturing Cost Estimation . (2020).

38. BYD. Build Your Dreams New Energy. (2017).

39. Miles, A. The Secret Life Of An EV Battery. CleanTechnica (2018).

40. Electric Reliability Council of Texas. DAM Ancillary Service Plan. Available at: http://mis.ercot.com/misapp/GetReports.do?reportTypeId=12316\&reportTitle=DAM Ancillary Service Plan\&showHTMLView=\&mimicKey. (Accessed: 14th December 2020)

41. California Public Utilities Commission. RPS Procurement Rules. Available at: https://www.cpuc.ca.gov/RPS_Procurement_Rules/. (Accessed: 15th December 2020)

42. Dan Pinkel, B. \& Weinrub, A. What the Heck is a REC? (2013).

43. California Independent System Operator. Finance Department GMC and Other Rates for 20042020. (2020).

44. Oncor Electric Delivery Company LLC. TARIFF FOR RETAIL DELIVERY SERVICE. (2017).

45. Fu, R. et al. 2018 U . S . Utility-Scale Photovoltaics- Plus-Energy Storage System Costs Benchmark. Natl. Renew. Energy Lab. 32 (2018).

46. Electric Power Research Institute. Budgeting for Solar PV Plant Operations \& Maintenance : Practices. (2015).

47. International Renewable Energy Agency. Data \& Statistics. Available at: https://www.irena.org/statistics. (Accessed: 14th December 2020)

48. Julian Turner. Can the US railroad freight sector avoid a shortage of boxcars? Railway Technology Available at: https://www.railway-technology.com/features/us-railroad-freight-boxcars/.

(Accessed: 14th December 2020) 
49. U.S. Energy Information Administration (EIA). What is U.S. electricity generation by energy source? Available at: https://www.eia.gov/tools/faqs/faq.php?id=427\&t=3. (Accessed: 14 th December 2020)

50. U.S. Interagency Working Group on Social Cost of Greenhouse Gases. Technical Support Document: - Technical Update of the Social Cost of Carbon for Regulatory Impact Analysis Under Executive Order 12866. (2016).

51. U.S. Environmental Protection Agency. Emission Factors for Greenhouse Gas Inventories. (2014). doi:10.1177/0160017615614897

52. U.S. Energy Information Administration. How much carbon dioxide is produced when different fuels are burned? Available at: https://www.eia.gov/tools/faqs/faq.php?id=73\&t=11. (Accessed: 14th December 2020)

53. U.S. Energy Information Administration. Annual Coal Report. 87 (2020). 


\section{Figures}

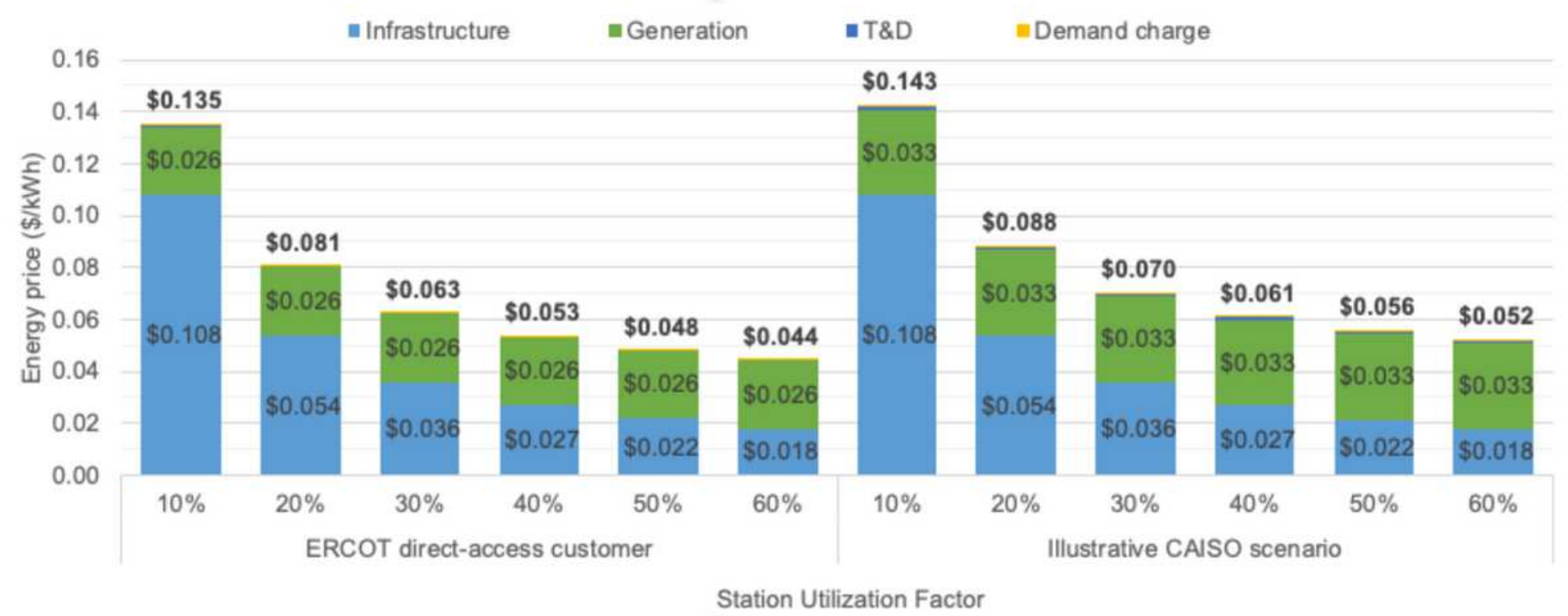

Figure 1

Energy prices $(\$ / \mathrm{kWh})$ inclusive of fast-charging infrastructure at various station utilization rates in ERCOT and CAISO. The ERCOT market assumes rail customers have access to wholesale prices. The illustrative CAISO market assumes ERCOT's critical peak pricing (CPP) rate structure and no resource adequacy surcharges. Baseline assumptions include an $80 \%$ depth of recharge, 10 tender cars per station, 1-hour charge time, 7\% capital expenditure revenue return,27 and 10\% efficiency losses in power conversion. Station lifetimes are estimated at 20 years. Generation prices are average hourly prices observed for each market for all hours 2017-2019. 


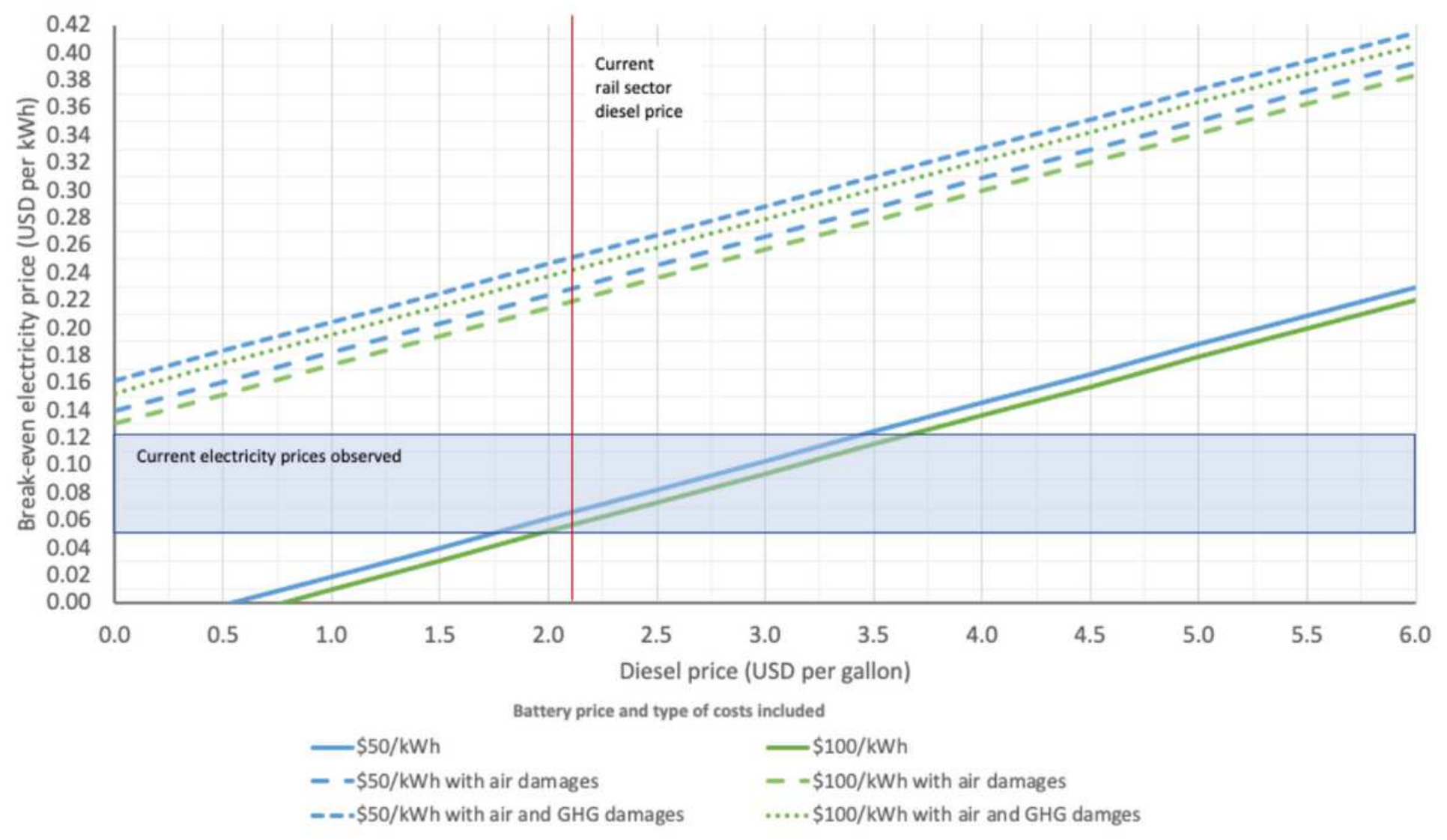

\section{Figure 2}

All-inclusive electricity prices (electricity cost plus charging-infrastructure cost) needed to reach diesel parity based on total cost of ownership (TCO), assuming near-term and projected battery prices with LFP technology over a 20-year horizon. The solid lines do not include environmental damages, the dashed lines include criteria air pollutant damages only, and dotted lines include damages from both criteria air pollutants and GHG emissions. At current wholesale diesel prices of $\$ 2.12 /$ gallon and ignoring environmental damages, all-inclusive electricity prices would need to approach $\$ 0.057 / \mathrm{kWh}$ with battery prices at $\$ 100 / \mathrm{kWh}$ and $\$ 0.066 / \mathrm{kWh}$ with battery prices at $\$ 50 / \mathrm{kWh}$ to compete with diesel. These estimates are based on a locomotive with a 150-mile range pulling 1,211 revenue-tons with TCO annualized over a 20 -year horizon and $3 \%$ discount rate. Environmental savings are estimated using $100 \%$ renewable electricity generation. 


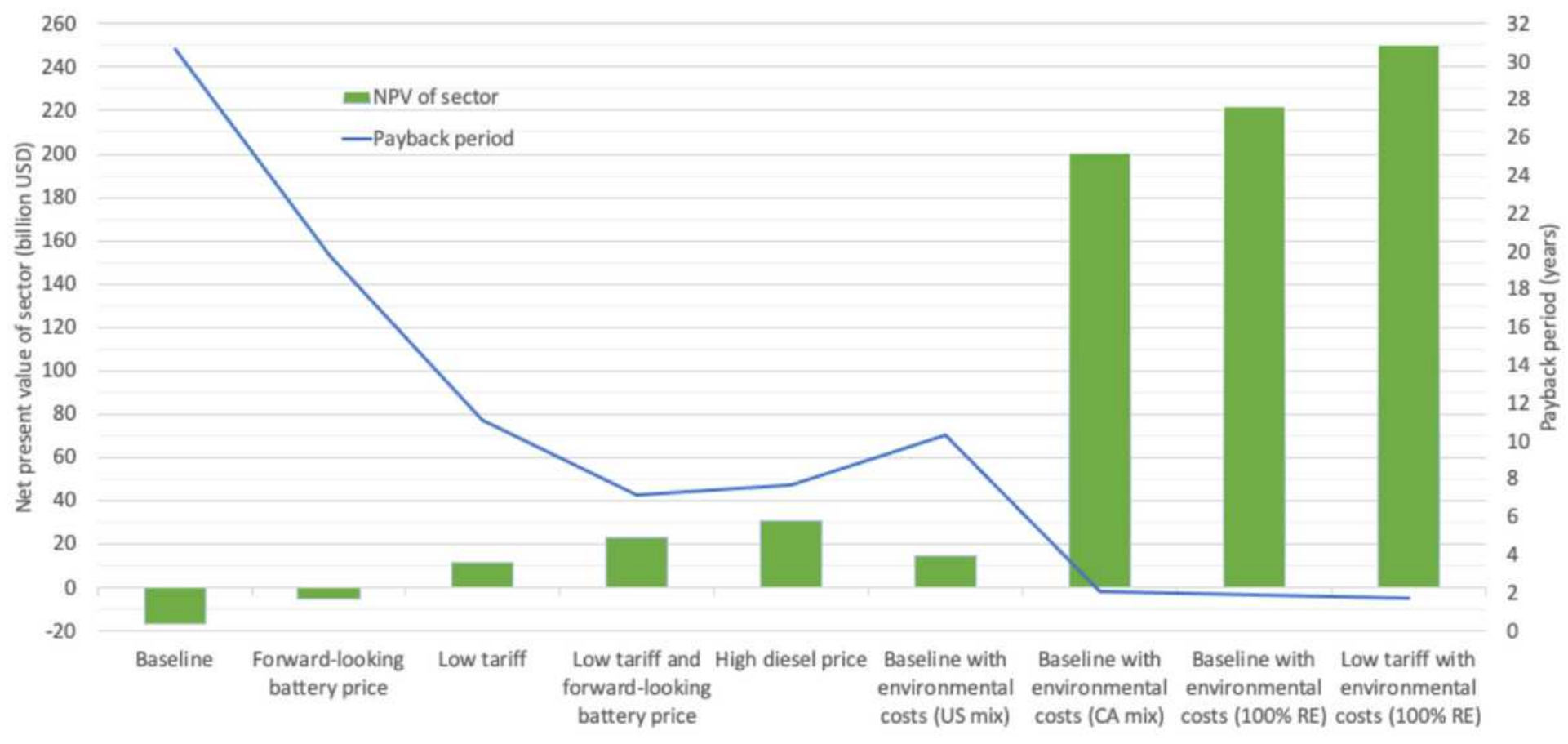

\section{Figure 3}

NPV of savings over 20 years for the U.S. freight rail sector. The line corresponds to the right $y$-axis and represents the payback period per locomotive in years. The columns correspond to the left $y$-axis and represent the NPV of the rail sector using LFP battery technology. All scenarios are based on a 150-mile range for a 3.3-MW locomotive pulling 1,211 revenue-tons. The baseline scenario assumes a $\$ 2.12 /$ gallon diesel price, $\$ 100 / \mathrm{kWh}$ battery price, $\$ 0.070 / \mathrm{kWh}$ electricity-plus-charging-infrastructure price (assumes $25 \%$ station utilization rate), and $3 \%$ discount rate. The forward-looking battery price is $\$ 50 / \mathrm{kWh}$. Break-even sector NPV occurs at station utilization rates of $35 \%$, with tariffs at $\$ 0.057 / \mathrm{kWh}$. The low electricity tariff inclusive of fast-charging infrastructure is $\$ 0.048 / \mathrm{kWh}$ (assumes $50 \%$ station utilization rate). The high diesel scenario uses the baseline case with a $\$ 3 /$ gallon diesel price. Environmental savings are added to the baseline case and are estimated using U.S., California, and 100\% renewable electricity mixes. 